\title{
Latin America:
}

\section{The Region without Catalonia}

\author{
Tomasz Rudowski
}

(iD) https://orcid.org/0000-0001-8723-3058

University of Warsaw / Vistula University Institute of Iberian and Ibero-American Studies / School of Foreign Languages e-mail: tmrudowski@gmail.com / t.rudowski@vistula.edu.pl

\section{Piotr Sieniawski}

(iD) https://orcid.org/0000-0002-4654-7170

Cardinal Stefan Wyszyński University in Warsaw

Institute of Political Science and Administration

Department of International Relations and European Studies

e-mail: piotr.sieniawski@student.uksw.edu.pl

\section{Abstract}

The aim of this article is to analyse the issue of "weak separatism" in Latin America as well as to give an answer to the question why there are no significant separatist movements in this region. The authors provide the definitions of separatism and secessionism as well as an explanation of these phenomena. Moreover, they present an overview of historical and contemporary separatist movements in Latin America. Based on Horowitz's theory of ethnic separatism, the authors attempt to analyse the separatist movement "The South is My Country" in Brazil and compare it with separatism in Catalonia in Spain, where a referendum on independence from Spain was held in 2017, serving as an impetus for a similar referendum that took place in the South of Brazil. In spite of similar goals of these two separatist movements, the authors argue that there are significant differences in their nature, which are determined by the history and culture of the respective countries.

Keywords: Latin America, Separatism, Secession, Catalonia, The South is My Country, O Sul é o Meu País 


\section{Introduction}

The problem of ethnic separatism is a very topical issue and poses a significant challenge for the international society. The year 2018 marks the tenth anniversary of the unilateral declaration of independence of Kosovo and also the first anniversary of the unilateral declaration of independence of Catalonia. Latin America is linked to Spain not only by history, language and culture but also by investments and the common project of democracy (transition from authoritative regimes). Thus, it is no surprise that due to this closeness the conflict over the future of Catalonia was present in the Latin American media and also affected the public opinion (Sánchez; Giorgi). It has also awakened the growing Latin American separatist movements. Moreover, the choice of the name of the movement "The South is My Country" (Portuguese: O Sul é o Meu País) in the southern states of Brazil was caused by the fact that it had drawn inspiration from the Catalan way towards independence.

In this article, different "theoretical lenses," through which we may perceive separatism will be used in order to better understand the above issues. The authors believe that by applying analytic eclecticism they may analyse those issues in a more profound way (Sil and Katzenstein). Such an approach will help overcome the limitations which stem from the use of methods and tools designed for a single paradigm. In this case, the neo-structural and constructivist paradigms will be applied.

The article deals with conflicts between the centre and the periphery in the respective states. The relationships of dependence and peripherality are created within states and, therefore, internal centres as well as internal peripheries emerge. In the history of Spain and partly in the history of Latin America, there were regions which posed challenges to their political "centres." However, they differed in the degree of confrontation (from aspirations for increased autonomy to secession). Based on the cases of Bolivia and Peru, Alberto Vergara attempted to answer the question why some peripheries openly defy their centres, while others do not oppose them at all. While trying to explain the divergent outcomes through a comparative historical analysis, he proposed that

conflicts between centres and peripheries should be studied using two analytical dimensions. The first dimension is the presence or absence of a regional elite that could shape legitimate politicals organisations and discourses, articulating regional demands and bargaining with the central state. The second assesses the region's structural conditions, specifically the relevance of natural resources and the size of its population (Vergara IV, 5).

The resistance of the periphery against the centre is a result of the power of peripheral elites, strengthened by its access to natural resources and the potential 
of the population. Furthermore, in Alberto Vergara's view, access to foreign trade and a principal city that rivals the national capital are notably important. Although this thesis concerned the Bolivian movement, which focused on the independence of the Santa Cruz department, the aim of the authors of this article is to verify whether the thesis may be applied to other regions of Latin America and Catalonia.

\section{Secessionism, separatism, and their explanation}

With respect to secession and processes which precede secession, one may often encounter the term "separatism." At first glance, it may be associated with separation as a mode of state creation, in which withdrawal from a state is regulated by a constitutional mechanism. However, many authors link this term with secession or use the two terms interchangeably. J. R. Wood defines separatism as "a desire for the reduction of control by a certain authority in a specific area ... [which] may be expressed in demands for provincial rights or local or regional autonomy in certain spheres of decision-making" (110). Separatism may often result in "splitting a smaller territorial governance unit from a larger one" (Hechter 3 ). D. Horowitz uses the terms "separatism" and "secession" as synonyms, which encompass "movements seeking a separate region within an existing state, as well as those seeking a separate and independent state" (232). In social sciences, separatism may lead a minority ethnic group (nationality or national minority) to pursue autonomy of a region which comprises an integral part of the territory of a state within the framework of the parent state; to secession of that region and creation of an independent state; or to integration of that region with the kin state (in the case of national minorities).

J. Dugard noted that " $[\mathrm{t}]$ here is no agreement on the precise meaning of secession. Sometimes the term is used in the broad sense to include both the dismemberment and dissolution of States" (18). Secession can be defined as a unilateral withdrawal of an integral part of the territory of a state and its residents from the state, which happens without the consent of the parent state (Haverland). This process results in the creation of a geopolitical unit which is independent from the previous state and aims to become a separate state or accede to another existing state. The previous state, however, still exists as a subject of international law (Sieniawski 898). It follows from the above definitions that separatism is a broader term than secession, which may be manifested through the effort of a national minority or an ethnic group to gain autonomy or independence. The most extreme expression of separatism is secession. Also, it is important to note that secession is a legal term describing an institution of customary international law, whilst separatism is a term used in social sciences. This, however, does not limit secession purely 
to legal science. On the contrary, it is an interdisciplinary phenomenon concerning mostly international relations, international law, and security studies (Biermann 158; Siroky 45).

In this article, Horowitz's theory of secession, based on the level of cultural and economic development of ethnic groups as well as on the economic development of the regions they inhabit, will be applied. With regard to the level of economic and cultural development, he differentiates between advanced and backward groups. An advanced group is characterised by benefitting from opportunities in education and non-agricultural employment and also by a relatively high income per capita. On the other hand, a backward group is characterised by less favourable opportunities in education and by a lower income per capita. The difference between an economically advanced and an economically backward region stems from their position in the national economy as well as from the income per capita. Based on the combination of the above criteria, four models can be distinguished:

a) Backward group in a backward region. An example of such a combination is South Sudan or the Kurds in Iraq. The ethnic groups are not interested in preserving the unity of the parent state and usually secede early. They also demand their own political representation, but due to their backwardness, they lack eligible candidates. The ambition to become independent prevails over potential economic losses that might be caused by secession.

b) Backward group in an advanced region. Horowitz regards Katanga as such a case. The members of a backward group are treated as second-class citizens compared to the members of a dominant group, who often internally colonise the region and take up employment opportunities.

c) Advanced group in a backward region. According to D. Horowitz, it is e.g. the Ibo people in Nigeria. The members of an advanced ethnic group often search for opportunities outside of their home region. Thus, secession happens relatively late and only as a last resort in case of serious discrimination and a threat to the group's survival, since the economic costs of secession for the backward region are high.

d) Advanced group in an advanced region. The Basque Country or Catalonia in Spain qualify for this category. In such a combination, secession is quite unlikely, given that the economic ties discourage the separatist group from secession. Ethnic groups in an advanced region are usually ambivalent to secession: on the one hand, they are subsidising poorer regions, but on the other hand they prefer to stay in the common state, because the state protectionist policy grants them outlets for their goods outside of their own region. The reason for separatist tendencies is the belief that the ethnic groups "generate more income 
and contribute more revenue to the treasury of the undivided state than they receive" (250-51). The ethnic groups secede only if economic costs are low and secessions occur late and rarely.

\section{An outline of separatist movements in Latin America}

Nationalism played a different role in Latin America than in Europe, where it served as a foundation of nation-states. Nationalism appeared in Latin America in the period of the wars of independence. The independence was, however, not the effect of nationalism, but rather a result of the weakening position of Spain and the loss of control over its colonies (Lomnitz 352).

Nationalism in Latin America was created from above by the state and its institutions. Although it has brought many benefits in building a nation-state, the nation-building process cannot yet be considered finished, and the regional separatist movements can make it more dynamic. The benefits of nationalism in Latin American include homogenisation of the societies, building of national identity, reduction of separatism and regionalism as well as social and cultural consolidation (Paleczny 44-45).

In terms of civilisation, Latin America constitutes a relatively homogenous region. The most significant bonds of the region include the common colonial legacy, mixture of ethnicities, language (Spanish and Portuguese), religion (Christianity with the predominance of Catholicism), hybrid culture (stemming from European cultures with strong Iberian influence) with autochthonous cultures, and influx from other regions of the world.

The relatively low support for separatist movements in the region, according to Eric J. Hobsbawm, might be attributed to the popularity of federal constitutions as well as to the weakness and ineffectiveness of the central state, which, in contrast to Europe, leaves plenty of space for an effective local autonomy (Hobsbawm 341). Even though Latin America was not free from devastating civil wars, it should be emphasised that, to a large extent, it was able to avert the problem of separatism in spite of numerous languages and national and geographic divisions in the region. There are, in fact, many reasons why Latin America has no "Catalonia." As A. Vergara has noted, "for regional grievances to become separatist movements requires some specific conditions. These include powerful regional political elite, access to economic resources and foreign trade, and a paramount city that rivals the national capital. They applied to the Bolivian movement centred on Santa Cruz. And they apply in Catalonia" (Reid). 


\begin{tabular}{|c|c|c|c|}
\hline State & Secessionist movement & Period & Results \\
\hline \multirow[t]{6}{*}{ Brazil } & Constitutionalist revolution of 1924 & 1924 & Attempt to create the Republic of São Paulo \\
\hline & $\begin{array}{l}\text { Different parts of Parnambuco, Paraiba, and } \\
\text { Ceará }\end{array}$ & 19th century & $\begin{array}{l}\text { Creation of the Confederation of the Equator } \\
\text { (1824) }\end{array}$ \\
\hline & Frente de Libertação da Republica Catarinense & $19^{\text {th }}$ century & Creation of Juliana Republic (1839) \\
\hline & Manifest Acclaim of Amador Bueno & 1887 & Attempt to create the Republic of São Paulo \\
\hline & Paulista revolt & 1924 & Attempt to create the Republic of São Paulo \\
\hline & Movimento da República Rio-Grandense & 19th century & $\begin{array}{l}\text { Creation of the Rio-Grandense Republic (1836- } \\
1845)\end{array}$ \\
\hline \multirow[t]{2}{*}{ Colombia } & Panama (department, supported by the U.S.) & 1899-1903 & Secession of Panama (1903) \\
\hline & Antioquia & $19^{\text {th }}$ century & $\begin{array}{l}\text { Attempt by the Department of Antioquia to } \\
\text { secede from Colombia }\end{array}$ \\
\hline Cuba & Partido Independiente de Color & 1912 & $\begin{array}{l}\text { Attempt to establish a separate black republic, } \\
\text { suppressed by force }\end{array}$ \\
\hline Haiti & South Department & $1810-1812$ & Secession of the South Department (1810-1812) \\
\hline
\end{tabular}




\begin{tabular}{|c|c|c|c|}
\hline \multirow[t]{8}{*}{ Mexico } & American mercenaries around W. Walker & $1853-1854$ & $\begin{array}{l}\text { Secession from Mexico, creation of the Republic } \\
\text { of Baja California (1853-1854) }\end{array}$ \\
\hline & American mercenaries around W. Walker & 1854 & $\begin{array}{l}\text { Secession from Mexico, creation of the Republic } \\
\text { of Somora (1854), attempt to create a fortified } \\
\text { U.S. frontier }\end{array}$ \\
\hline & Anglo settlers around Benjamin Edwards & $1826-1827$ & Creation of the Republic of Fredonia (1826) \\
\hline & Chan Santa Cruz & $19^{\text {th }}, 20^{\text {th }}$ century & $\begin{array}{l}\text { Creation of the Maya State (The State of the } \\
\text { Cross), de facto existence 1849-1915 }\end{array}$ \\
\hline & Insurgents in Sonoma (American immigrants) & 1846 & $\begin{array}{l}\text { Secession from Mexico, creation of the California } \\
\text { Republic (1846) }\end{array}$ \\
\hline & Mexican Texas & $1836-1846$ & $\begin{array}{l}\text { Secession from Mexico, creation of the Republic } \\
\text { of Texas }\end{array}$ \\
\hline & Republic of Yucatan & $1841-1848$ & $\begin{array}{l}\text { Secession from Mexico, creation of the Republic } \\
\text { of Yucatan }\end{array}$ \\
\hline & States Coahuila, Nuevo León, and Tamaulipas & 1840 & $\begin{array}{l}\text { Secession from Mexico, creation of the Republic } \\
\text { of the Rio Grande (1840) }\end{array}$ \\
\hline Panama & Guna people & 20th century & Guna District of San Blas established in 1938 \\
\hline
\end{tabular}

Source: Authors' own compilation based on: Mroziewicz, Stemplowski, Dzieje Ameryki Łacińskiej, vol. 2; Mroziewicz, Stemplowski, Dzieje Ameryki Łacińskiej, vol. 3 


\begin{tabular}{|c|c|c|c|}
\hline State & Secessionist movement & Demands & Grievances \\
\hline \multirow[t]{2}{*}{ Argentina } & $\begin{array}{l}\text { Consejo de Todas las Tierras (Mapuche } \\
\text { people) }\end{array}$ & Secession of Wallmapu & Education; culture; representation \\
\hline & $\begin{array}{l}\text { Movimiento independentista } \\
\text { Patagónico }\end{array}$ & Secession of Patagonia & Economic inequalities \\
\hline Bolivia & $\begin{array}{l}\text { El Movimiento Nación Camba } \\
\text { de Liberación (MNCL) }\end{array}$ & $\begin{array}{l}\text { Creation of the Republic of Santa Cruz, } \\
\text { consisting of the departments Santa } \\
\text { Cruz, Beni, Pando, and Tarija }\end{array}$ & $\begin{array}{l}\text { Economic; cultural; political; } \\
\text { sociological (internal colonisation) }\end{array}$ \\
\hline \multirow[t]{5}{*}{ Brazil } & Acre & $\begin{array}{l}\text { Secession of the region of Acre from } \\
\text { Brazil }\end{array}$ & $\begin{array}{l}\text { Cultural (native peoples); economic } \\
\text { (exploitation of raw materials); political }\end{array}$ \\
\hline & $\begin{array}{l}\text { Grupo de Estudo e Avaliação } \\
\text { Pernambuco Independente }\end{array}$ & Secession of Pernambuco from Brazil & Cultural (former Dutch colony) \\
\hline & $\begin{array}{l}\text { Movimiento Nordeste Independente } \\
\text { do Brasil }\end{array}$ & Secession of the North of Brazil & Economic; political \\
\hline & $\begin{array}{l}\text { Movimiento República Rio-Grandense } \\
\text { (Rio-Grande Republic Movement) }\end{array}$ & Secession of Rio Grande & Economic; cultural \\
\hline & $\begin{array}{l}\text { Movimiento Sâo Paulo Independente, } \\
\text { Movimiento República de Sâo Paulo, } \\
\text { Sâo Paulo Livre }\end{array}$ & $\begin{array}{l}\text { Secession from Brazil, creation of } \\
\text { the Republic of Sâo Paulo }\end{array}$ & Cultural; political \\
\hline
\end{tabular}




\begin{tabular}{|c|c|c|c|}
\hline Brazil & O Sul é Meu País & $\begin{array}{l}\text { Secession of Paraná, Santa Catarina } \\
\text { and Rio Grande de Sul from Brazil }\end{array}$ & $\begin{array}{l}\text { Political (underrepresentation); } \\
\text { economic; cultural }\end{array}$ \\
\hline \multirow[t]{2}{*}{ Chile } & Consejo de Todas las Tierras & $\begin{array}{l}\text { Secession from Chile and creation of } \\
\text { the Mapuche State }\end{array}$ & $\begin{array}{l}\text { Cultural; economic; political (offences } \\
\text { prosecuted as terrorist acts) }\end{array}$ \\
\hline & Easter Island (Rupa Nui people) & Secession of Easter Island from Chile & Cultural \\
\hline Colombia & $\begin{array}{l}\text { Archipelago Movement for Native } \\
\text { Self-Determination }\end{array}$ & $\begin{array}{l}\text { Secession of Archipelago of San } \\
\text { Andrés, Providencia and Santa } \\
\text { Catalina, and creation of their own } \\
\text { state (San Andrés y Providencia) }\end{array}$ & Cultural; political \\
\hline Costa Rica & Independentisimo guanacasteco & $\begin{array}{l}\text { Secession of the province of } \\
\text { Guanacaste }\end{array}$ & Cultural; political (marginalisation) \\
\hline Equador & Guayaquil & $\begin{array}{l}\text { Alleged secessionism (regarded } \\
\text { as secessionist by the central } \\
\text { government), infighting between Costa } \\
\text { and Sierra }\end{array}$ & Economic; cultural \\
\hline Mexico & $\begin{array}{l}\text { Mexico City, México State, Jalisco, } \\
\text { Nuevo León, Veracruz }\end{array}$ & $\begin{array}{l}\text { Secession from Mexico, creation of } \\
\text { the Republic of Northern Mexico }\end{array}$ & $\begin{array}{l}\text { Educational; economic; political; } \\
\text { cultural }\end{array}$ \\
\hline Nicaragua & Miskito people & $\begin{array}{l}\text { Secession from Nicaragua } \\
\text { (independence declared in April 2009) }\end{array}$ & $\begin{array}{l}\text { Economic (exploitation of natural } \\
\text { resources by the central government) }\end{array}$ \\
\hline Venezuela & Rumbo Propio & $\begin{array}{l}\text { Autonomy for the Zulia State (regarded } \\
\text { as secessionist by the central } \\
\text { government) }\end{array}$ & Economic; cultural; political \\
\hline
\end{tabular}




\section{"The South is My Country"}

The Federative Republic of Brazil is a federation composed of 26 states, the Federal District, and 5,570 municipalities. Pursuant to Article 1 of the 1988 Constitution, "[t]he Federative Republic of Brazil [is] formed by the indissoluble union of States and Counties (municipios), as well as the Federal District" (Brazil's Constitution of 1988 with Amendments through 2017). Brazil declared its independence from Portugal in 1822 and only a few years later experienced the attempt of Rio Grande do Sul to secede, which was supported by Giuseppe Garibaldi. In 1836, the secessionists managed to create their own quasi-state, which lasted up to 1845 (Carmagnani).

Brazil is currently facing a secessionist movement "The South is My Country" (in Portuguese O Sulé o Meu País), which was formed in 1992 in the city of Laguna. It claims that the three southernmost states of the Federation, Paraná, Rio Grande do Sul and Santa Catarina, which altogether cover an area that could be compared to France, should secede from Brazil and create their own state.

The grievances that have been raised by the movement "The South is My Country" (hereinafter referred to as "Movement") could be divided into three major groups:

1. Economic: According to the Movement, the redistribution of tax revenues is discriminatory in favour of poorer regions in the north. Nevertheless, it is the south that makes the largest contributions into the state budget. The gross regional product in 2016 was USD 10,242 in Paraná, USD 10,379 in Rio Grande, and USD 10,648 in Santa Catarina (Instituto Brasileiro de Geografia e Estatistica). The average gross domestic product of Brazil per capita was USD 8,650 in the same year (Brazil-GDP per capita). Between 2011 and 2016, Brazil received $80 o b n$ reals in taxes from the three southern states, but invested back only 16 obn reals, i.e. $20 \%$, which makes the central government look as an exploiter. Another reason is the ongoing economic stagnation in Brazil, which encourages the more prosperous south to secede from the rest of the country (Schipani). In Horowitz's theory, the south of Brazil corresponds to the "advanced group in an advanced region" which subsidises the state but receives very little in return.

2. Political: The three states claim to be underrepresented on the federal level. As in January 2019, the three southern states were represented in the Chamber of Deputies (lower chamber) by 77 deputies out of 513 (15\%). Among other problems that Brazil is currently facing, and which cause dissatisfaction in the South, are corruption and a high level of crime. According to Homicide Monitor, there were more than 30 murders per 100,000 inhabitants in Brazil in 2016, making Brazil one of the most dangerous countries in the region. 
3. Cultural: The inhabitants of the three southern Brazilian states are mostly descendants of German, Italian and Portuguese immigrants, and "many take pride in a European sense of organisation" (Phillips). Although the language in the region does not differ from the rest of Brazil, German and Italian are still spoken in some areas in the south. This makes a significant cultural difference from the north of the country, where "the population has more black and mixedrace people and slavery was more prevalent from the $16^{\text {th }}$ to the $19^{\text {th }}$ centuries" (Phillips).

In October 2016, a referendum on the independence of the three states was held. The referendum was neither official nor legally binding, and the turnout was less than $3 \%$ of the registered voters. Out of these, almost $96 \%$ voted in favour of secession. Another referendum on independence was held on October 7, 2017, but only slightly more than $1 \%$ of the registered voters participated.

The separatist movement "The South is My Country" does not currently pose any direct threat to the territorial integrity of Brazil. Nevertheless, the criticism against the economic and political situation is very likely to persist. Despite the low turnout in the referenda, the separatist movement has the potential to grow stronger in the future and cause serious disturbances on the national level.

\section{The case of Catalonia}

Even though the Catalan identity dates back to the Middle Ages, there was no self-perception of a nation in the modern sense (Balcells 9). The historical roots can be seen with the creation of the Spanish March, whose aim was to protect the Carolingian state from the Arabs (Kark 3). The first mention of "Catalonia" dates to 1150 in a series of pacts concluded by the King, which were called Usatges (the customs that form the basis for the Catalan Constitution) and which "explicitly acknowledged legal equality between burghers and nobility" (Woolard 17).

In the nineteenth century, structural differences between Catalonia and the rest of the country were becoming more and more noticeable. "In Catalonia, there is active bourgeoisie and all kinds of middle classes [...] interested in protectionism, political freedom and in the increase of the purchasing power. In Spain, the old lifestyle dominates: a peasant cultivates the land to eat, but not to sell the products; the owner does not accumulate the capital and does not invest" (Vilar 100102). Since then, in the discussions on taxation, the Catalans have been accused of the lack of solidarity with the rest of Spain, while the Spanish state has been portrayed by the Catalans as "the exploiter." This resulted in two inferiority complexes, namely in "the political complex in Catalonia and the economic complex in Castile, which produced invincible distrust" (Vilar 102; Cf. Conversi 18). 
Throughout the nineteenth century, the so-called "double identity" or "double patriotism" was present in Catalonia, which was caused by the nostalgia for old institutions and the feeling of being integrated with the Spanish nation within the federal system (Fradera 87-100). In 1866, the Catalan Day (Diada) was celebrated for the first time. The groups of Catalan nationalists from Barcelona spread symbols of identity to the provinces. In 1901, the Regionalist League of Catalonia was formed (a conservative party aspiring to gain autonomy for Catalonia), won the elections a few years later, and belonged to the most important parties for several years. It was the time of the deep collapse of Spain after the loss of the colonies in 1898 (Cuba imported 6o\% of the Spanish export) (Balcells 44). In 1931 and 1934, the heads of the Catalonian government (Francesc Macià and Lluís Companys, the left-wing Catalan nationalist leaders) proclaimed the Catalonian Republic within the Federal Republic of Spain (the Second Spanish Republic). In both cases, they were pacified by the central government. During the dictatorship of General Francisco Franco, great emphasis was put on promoting the Castilian culture at the expense of Catalonia, which made the sense of Spanishness (hispanidad) in the region very weak (El nacionalismo catalán). The last 30 years were marked by a radical evolution and an increase in the support for separatism. Since then, there has been strong emphasis on portraying the suffering of the nation under the Spanish rule. A significant tool in the hands of the Catalonian authorities was the issue of education and the revival of the Catalan language, which once again gained the status of an official language (Ucelay).

The fact that the Catalonian Autonomous Community enjoys broad autonomy compared to other communities in Spain and Europe has not stopped its leaders from dreaming about secession. One of the key elements of the contemporary Catalan identity is the belief of superiority within the Spanish economy. The region is inhabited by approximately $16 \%$ of the citizens of Spain, produces about $20 \%$ of the GDP, constitutes $25 \%$ of the export potential, and is considered one of the richest regions in the European Union (Cuadras 7, 149-85). The separatist aspirations of the Catalans escalated with an increasing economic recession in Spain. The view that being an integral part of Spain is not profitable and that Catalonia ssubsidises other regions prevails in the discourse on separatism. Currently, Barcelona is the economic centre of the region, inhabited by about two-thirds of the region's population and accumulating the majority of investment capital (Romei). Throughout the years, Barcelona has competed with Madrid over the headquarters of large corporations.

One of the most important events in the contemporary history of Catalonia was the adoption of the new Statute of Autonomy in 2006, which further broadened the autonomy of the region. Four years later, a number of new competencies were questioned by the Spanish Constitutional Court, which a large part of the Catalan society perceived as an attack on their rights and strengthened their belief that the Constitutional Court was subordinated to the central government in Madrid 
(Kalinowski 184-85). Decisive for the Catalan road to independence was the adoption of the Declaration on the Sovereignty by the Catalan Parliament on January 23, 2013, which stated that the people of Catalonia had the status of a sovereign political and legal entity. Once again, in the view of the Spanish Constitutional Court, the above Declaration was illegal and had no legal effects. The Catalan political elites, striving for more autonomy, responded by organising a new "consultation" on the independence in 2014, which was not binding (Pérez).

In the early parliamentary elections in Catalonia held on September 27, 2015, the pro-independence movement, led by the platform Junts pel Sí, ${ }^{1}$ scored victory. Despite condemnation by the central government, the new regional government called for a referendum on independence, which took place on October 1, 2017. The independence option was supported by more than 90\% of the Catalans with a $42.3 \%$ turnout. It needs to be emphasised that the government tried to disrupt the organisation of the illegal referendum, which resulted in more than 800 persons injured (Dearden). Subsequently, the Spanish government invoked Article 155 of the Spanish Constitution in order to "restore order" in Catalonia, imposing a temporary direct rule upon the region. Also, the members of the Catalan government were arrested and another election was held, in which the independence movement succeeded again. The fact that Mariano Rajoy, the head of the Spanish government, was replaced by Pedro Sanchez meant a slight improvement in the relationship between the central and the regional governments, since Sanchez suspended the autonomy and resumed the dialogue with the new president of the Catalan government, Quim Torra.

Later, Prime Minister Sanchez proposed a referendum on greater autonomy for Catalonia instead of its withdrawal from Spain (Torres). However, this has not put an end to the tumultuous times. Simultaneously, a decrease in the support for the monarchy is becoming more and more apparent. This can be also attributed to King Felipe VI's public speech held after the referendum, which did not help ease the tension in the society.

\section{Conclusion}

Separatism in Latin America is of a different nature than in the "Old World", due to the fact that it has very little in common with nationalism. Nationalism in Latin America was created from above, i.e. by the state and its institutions. The army played a significant role in this process and sometimes the nationalist ideas were promoted by political parties. Thus, it can be stated that nationalism in Latin

1 The Platform consisted of four parties: Democratic Convergence of Catalonia (CDC), the Republican Left of Catalonia (ERC), Democrats of Catalonia (DC), and the Left Movement (MES). 
America is a creation of the state elites that developed after the colonial era. Unlike in other regions of the world, nationalism in Latin America does not pose any threat to international order (Łaciński 8).

Some states in Latin America, such as Brazil and Mexico, have transformed the idea of national unity into a significant political project. A completely different situation was present in Catalonia, where the national identity, having its roots in the Middle Ages, is very strong. Breakaway tendencies have been present since the nineteenth century. The issue of independence of Catalonia often appeared in the twentieth century together with demands for larger autonomy. At the beginning of the twenty-first century, the Catalans' struggle for more competencies reappeared. Moreover, the economic crisis in Spain has contributed to the growth of pro-independence feelings.

When analysing the situation in Latin America, it should be concluded that neither linguistic nor ethnic divisions encourage separatism. The populations of indigenous peoples (often speaking different languages) are too dispersed to struggle for their independence. Instead, they are struggling for broader autonomy and more rights to preserve their culture and to be treated as full citizens (Reid; cf. Rudowski, Koncepcja ... 46-48; Rudowski, Vías ... 72, 77-78). The separatist movements in Catalonia serve as an impetus and inspiration for similar movements in Latin America, which can be illustrated on the example of the movement "The South is My Country" and its activities. In spite of its effort to secede from Brazil, it currently does not pose any direct threat to the territorial integrity of Brazil.

Inner relations within the analysed states can be described as "reversed centre - periphery." This term was invented by the Spanish geographer José R. Lasuén, by which he referred to the situation in Spain, where Madrid is the political centre, whilst Barcelona and Catalonia are the political periphery and simultaneously the economic centre (Lasuén 475-526). In the authors' view, this concept can be applied to other regions as well. Although no changes are expected on the political map of Latin America, the future alone will show the development of the separatist movements in Latin America and their achievements.

\section{Works Cited}

Balcells, A. Catalan Nationalism: Past and Present. New York: St. 'Martin's Press, Inc., 1996.

Biermann, R. "Secessionism, Irredentism and EU Enlargement to the Western Balkans. Squaring the Circle?" European Integration and the Transformation. Europeanization or Business as Usual? Ed. A. Elbasani, London-New York: Routledge, 2013, pp. 157-169. 
Brazil - GDP per capita. “Index Mundi.” Web. 20 January 2019 https://www. indexmundi.com/facts/brazil/gdp-per-capita

Brazil's Constitution of 1988 with Amendments through 2017. Web. 10 January 2019 https://www.constituteproject.org/constitution/Brazil_2017.pdf?lang=en

Carmagnani, M. (Ed.), Federalismos latinoamericanos: México, Brasil, Argentina. Ciudad de México: Fondo de Cultura Economica, 2016.

Conversi, D. The Basques, the Catalans, and Spain: Alternative Routes to Nationalist Mobilisation. London: Hurst \& Company, 1997.

Cuadras Morató, X. Catalonia: A New Independent State in Europe?: A Debate on Secession within the European Union. London-New York: Routledge, 2016.

Dearden, L. "Catalan Referendum: Clashes with Police Leave Nearly 900 Injured." The Independent (2 October 2017). Web. 14 December 2018 https://www. independent.co.uk/news/world/europe/catalan-referendum-police-clashesviolence-900-injured-government-independence-vote-banned-latestmossos-a7978166.html

Dugard. J., The Secession of States and Their Recognition in the Wake of Kosovo. The Hague: The Hague Academy of International Law, 2013.

EconoArs, "Nuestras Cataluñas: regiones independentistas de América Latina." (2 October 2017). Web. 21 January 2019 https://www.econoars.com/ blog-magazine/nuestras-catalunas-regiones-independentistas-de-america-latina El nacionalismo catalán, explicado en cuatro minutos. Video. Madrid: El País, 2017. Web. 14 December 2018 https://elpais.com/elpais/2017/10/09/ videos/1507575236_214157.html

Fradera, J. M. "El proyecto liberal catalán y los imperativos del doble patriotismo." Ayer 35 (1999): 87-100.

García Romero, L. “¿Focos secesionistas en América Latina?“ (2 November 2017) Estudios de Politica Exterior. Web. 10 January 2019 https://www.politicaexterior. com/focos-secesionistas-en-america-latina/

Gawrycki, M. F., Między autonomią a zależnością: polityka zagraniczna państw Ameryki Łacińskiej i Karaibów - stadium przypadków, Warszawa: ASPRA-JR, 2017.

Giorgi, J. “¿Y el separatismo en América Latina?” El Observador, (5 October 2017). Web. 21 December 2018 https://www.elobservador.com.uy/ nota/-y-el-separatismo-en-america-latina--2017105500

Hale, H. E., The Foundations of Ethnic Politics. Separatism of States and Nations in Eurasia and the World. Cambridge: Cambridge University Press, 2008.

Haverland, C. "Secession." Encyclopedia of Public International Law. Vol. 4, Amsterdam: North-Holland, 2000.

Hobsbawm, E. J. "Nacionalismo y nacionalidad en América Latina." Repensando la subalternidad. Miradas críticas desde / sobre América Latina. Ed. P. Sandoval, Lima: Instituto de Estudios Peruanos, 2009. 
Homicide Monitor. Web. January https://homicide.igarape.org.br/

Horowitz, D., Ethnic Groups in Conflict. Berkeley: University of California, 2008.

Instituto Brasileiro de Geografia e Estatistica. "Contas regionais do Brasil." Web.

18 January 2019 https://www.politicaexterior.com/focos-secesionistas-en-americalatina/; https:/www.ibge.gov.br/estatisticas-novoportal/economicas/contasnacionais/9054-contas-regionais-do-brasil.html?=\&t=resultados\&fbclid=IwAR 21JOOt1_DB7EV8mLznM6W2f6lumYgKKh2SLtDFVJjvKavCZyv2wmTAcDY

Kalinowski, $€$. "Prawne aspekty secesji Katalonii." Internetowy Przeglad Prawniczy TBSP UJ 3 (2016): 183-85.

Kark, C. "From Parlor to Politics: Catalan Romantic. Nationalism as a Bourgeois Political Instrument." LL Journal 2 (2007). Web. 14 December 2018 https:// lljournal.commons.gc.cuny.edu/2007-2-kark-texto/

Lasuén J. R. “El estado multiregional.” La España de las autonomías. Ed. F. Fernández Rodríguez; M. Ferrer Regales, Madrid: Instituto de Estudios de Administración Local, 1985.

Lomnitz, C. "Nationalism as a practical system: Benedict Anderson's theory of nationalism from the vantage point of Spanish America." The Other Mirror: Grand Theory through the Lens of Latin America. Eds. M. A. Centeno, F. Lopez-Alves, Princeton: Princeton University Press, 2001.

Łaciński, P. „Wyzwania i uwarunkowania stabilności geopolitycznej Ameryki Łacińskiej." Ameryka Łacińska. Kwartalnik Analityczno-Informacyjny 3 (2017): 5-17.

Mroziewicz, R., Stemplowski, R. (Eds.). Dzieje Ameryki Łacińskiej, t. 2, Warszawa: Książka i Wiedza, 1979.

Mroziewicz, R., Stemplowski, R. (Eds.). Dzieje Ameryki Łacińskiej, t. 3, Warszawa: Książka i Wiedza, 1983.

Paleczny, T. Rasa, etniczność i religia w brazylijskim procesie narodowotwórczym. Kraków: Universitas, 2004.

Pérez, P. "1,8 millones de personas votan por la independencia catalana en el 9-N.” El País (10 November 2014). Web. 14 December 2018 https://elpais.com/ politica/2014/11/09/actualidad/1415542400_466311.html

Phillips, D. "A half-million Brazilians want to break away and form a new country." (6 October 2017). Financial Times. Web. 17 January 2019 https://www. washingtonpost.com/news/worldviews/wp/2016/10/05/half-a-million-brazilianswant-to-break-away-and-form-a-new-country/?utm_term=.142a60c2a7df

Reid, M. "Why Latin America Has No Serious Separatist Movements." The Economist (21 November 2017). Web. 14 December 2018 https://www.economist.com/ the-americas/2017/11/23/why-latin-america-has-no-serious-separatist-movements Romei, V. "Catalonia's Economic Strength Fuels Independence Push." Financial Times (28 September 2017). Web. 14 December 2018 https://www.ft.com/ content/62118282-a35a-11e7-b797-b61809486fe2 
Rudowski, T. "Koncepcja “ponownego założenia państwa”: przypadek Boliwii." Społeczeństwo i Polityka: pismo edukacyjne 1 (2017): 39-54.

Rudowski, T. "Vías a la modernidad. Noción y concepto de desarrollo en América Latina: un marco teórico.” Globalización y desarrollo sostenible. Eds. M. Czerny Mirosława, C. A. Serna Mendoza. Warsaw: Wydawnictwa Uniwersytetu Warszawskiego, 2018.

Sánchez, E. "El fantasma de Cataluña y los separatismos en América Latina." (27 October 2017). Web. 21 December 2018 https://aopinion-digital.com/opinion/ fantasma-cataluna-los-separatismos-america-latina/27-10-2017

Schipani, A. "Brazilians asked to vote on secession move." Financial Times (6 October 6 2017). Web. 17 January 2019 https://www.ft.com/content/ fcdf6460-aa52-11e7-ab55-27219df83c97

Sieniawski, P., “Secesia v súčasnom medzinárodnom práve” Právník 10 (2017): 894-914.

Sil, R. and Katzenstein, P. J. Beyond Paradigms: Analytic Eclecticism in the Study of World Politics. Basingstoke: Palgrave Macmillan, 2010.

Siroky, D., "Explaining Secession". The Ashgate Research Companion to Secession. Eds. A. Pavković, P. Radan. Farnham: Ashgate Publishing Ltd, 2011.

Torres, D. "Catalan leader rebuffs Madrid's offer on more autonomy." Politico (9 May 2018). Web. 14 December 2018 https://www.politico.eu/article/ catalan-leader-rebuffs-madrids-offer-on-more-autonomy/

Ucelay-da Cal, E., Breve historia del separatismo catalán. Barcelona: Ediciones B, 2018. Vergara Paniagua, P. "Conflicto regional, estado central y sociedad periférica en Bolivia y Perú. Un análisis histórico comparado.” Université de Montréal / Département de Science Politique (2012). Web. 21 December 2018 https://papyrus. bib.umontreal.ca/xmlui/bitstream/handle/1866/8782/Vergara_Alberto_2012_ these.pdf

Vilar, P. Historia de España. Paris: Librarie Espagnole, 1963.

Wood, J. R., "Secession: A Comparative Analytical Framework." Canadian Journal of Political Science 1 (1981): 107-34.

Woolard, K. A. Double Talk: Bilingualism and the Politics of Ethnicity in Catalonia. Stanford: Stanford University Press, 1989.

Tomasz Rudowski - Ph.D, a political scientist with a strong focus on Latin America. He holds a Bachelor's and a Master's in International Relations from the Institute of International Relations, University of Warsaw, as well as a Master's in Cultural Studies from American Studies Center, University of Warsaw. During his studies, he participated in an exchange programme at the Autonomous University of Madrid and in a research stay in Mexico within the Mexican Government Scholarship 
Programme. He also did an internship at the University of Amsterdam in 2016. His research is focused on socio-economical development, economic history as well as on international relations of Latin American coun-tries and the Caribbean.

Piotr Sieniawski - Ph.D. candidate at the Institute of Political Science and Administration, Cardinal Stefan Wyszyński University in Warsaw. He graduated from International Relations as well as Law, and completed traineeships in the National Council of the Slovak Republic, in the German Bundestag and in the European Commission. Alumnus of the Hague Academy of International Law. His research interests cover ethnic separatism, secessionism, de facto regimes as well as international law of armed conflicts. From 2018 to 2019, he was a visiting researcher at Ilia State University in Tbilisi, Georgia. 